UDC 811.111'42

DOI https://doi.org/10.32841/2409-1154.2021.49-1.14

\author{
Yemelyanova O. V., \\ Candidate of Philological Sciences, Associate Professor, \\ Associate Professor at the Department of Germanic Philology \\ Sumy State University \\ Novitchenko V.O., \\ Master's Student at the Department of Germanic Philology \\ Sumy State University
}

\title{
LINGUOPRAGMATIC FEATURES OF THE MODERN NEWS RELEASE
}

Summary. The article considers the linguopragmatic peculiarities of the modern news release. It is determined that the modern news release in English is a component of the public relations discourse (PR-discourse), which is aimed at forming a positive image of the company, product or service in the minds of the target audience. The news release is a short message, the purpose of which is to inform an addressee about any event in the life of the company or institution and create a positive impact on the audience. Ways of influencing depend on the target audience and the communicative situation.

The characteristic features of a modern news release are described, namely: informativeness, relevance, certainty, specificity, brevity, simplicity, versatility, adaptability which enhance the effectiveness of the message. It is determined that a news release is a syncretic type of text that combines official, journalistic and advertising functional styles. In turn, this determines the property of the news release to perform several communicative functions simultaneously. It is noted that the main features of the news release are foregrounded at the lexical, grammatical and syntactic levels. The main linguistic and stylistic features of the modern news release are described. The key typological characteristics of the news release, which are stipulated by the purpose of PR-communication, are studied, and it is noted that cultural specificity is one of the factors that determine the means by which the pragmatic effect on the addressee is achieved.

The structure of the news release is analysed. The news release explicitly answers the key questions what, when, where to navigate an addressee through the text of the news release. The researched material shows that the modern news releases being based on standard requirements for this type of a text, namely: the rigid format, brief and precise presentation of the information, size limitations that should not exceed A4 page for ease of perception, incorporate the visual images and pictures to facilitate the impact on the addressee.

Key words: PR-discourse, news release, addressee, linguistic and stylistic features, image, pragmatic effect.

Formulation of the problem. Public relations is an integral part of the effective operation of the company in modern economic environment. The urgency of the problems related to the field of PR-communication leads to the fact that they become the object of study of various sciences: linguistics, sociology, psychology, etc. One of the priority ways to disseminate information about the company and form public opinion is a news release.
In the field of social media, news releases have become a vital tool for the successful promotion and development of the company, its product or service. According to the definition offered by Collins Dictionary "a news release is a written statement about a matter of public interest which is given to the press by an organization concerned with the matter" [1]. The main task of the news release is to inform the addressee about a certain event in the life of the company or institution, its product or service.

A news release, also referred as a press release, was studied by the linguists from different perspectives. The scholars analysed the news release from the point of view of genre classification (P. Catenaccio [2]), they focus attention on the specifics of writing the press release (J. Robberts [3], P. Winston [4]), on the use of the quotes in the press release (P. Brown Jarreau [5]); they analyse the press release language (A. Davis, J. Piger, L. Sedor [6]), the specifics of the press release headlines (E. Guillamon-Saorin, B. Osma, M. Jones [7]); they investigate in what way newspaper journalists reframe product press release information (Maat H.P., Jong C. [8]), study the intertexuality and informativity of the press release (R. Superceanu [9]).

Despite a number of works focused on the research of the news release, a thorough comprehensive study of the linguopragmatic peculiarities of the modern news release has not been held so far, that constitutes the topicality of the research, performed within the framework of the anthropocentric paradigm. The aim of the study is to analyse the linguistic and pragmatic features of the modern news release distributed online.

The subject matter of the study is the text of the news release. The objective of the research is the linguistic and pragmatic features foregrounding in the modern news release.

Presentation of the main research material. The importance of PR-discourse research from the point of view of pragmatics is due to the fact that PR-communication is a form of social communication, which is produced in accordance with the main goal of the company, which is to "create a favorable image of the organization by promoting public opinion, increasing its popularity and developing mutually beneficial cooperation between the company and the public" [10, p. 117].

Within various types of discourse, different genres are distinguished. Some of genres encompassed by PR discourse include a news release, a newsletter, a fact sheet. Verbalization of the author's idea occurs with the help of texts written in a particular genre. A news release, as the genre of the PR-discourse, is 
focused on information dissemination about a certain company, its product or service.

The effectiveness and popularity of the news release is stipulated by its specific characteristics such as: informativeness the text of the news release is a statement of facts and does not contain unnecessary comments; relevance - that is ensured by the novelty of the information presented; credibility - that is guaranteed by the reliability of the official source of information provided; specificity - the content of the news release is limited to a certain informational reason; brevity, simplicity and efficiency of preparation that is stipulated by the dynamic news nature of the press release; limited text and monotonous content; universality - a press release is used as a basis for creating a wide range of secondary (journalistic) materials; processability - due to the extensive use of electronic communication for the news releases distribution [11, p. 87].

A news release belongs to the syncretic type of texts $[12 ; 10]$. This means that a typical news release is characterized by a combination of features of at least three functional styles - official, journalistic, and advertising. This is explained by the fact that the news release simultaneously performs several communicative functions - informative, expressive and appellate, etc. [13, p. 65]. Therefore, the purpose of the news release is primarily to inform and influence the potential recipient.

The diverse nature, as well as the performance of several communicative functions form the main features of the news release text, which are foregrounded at lexical, grammatical and syntactic levels. Yu. Diomin points out that press releases are characterized by: the economy of language means, their thorough choice to make the text more understandable; extensive use of clichés; use of words almost exclusively in their nominative meaning; predominance of verb-noun constructions; strict sequence of all parts of the text; use of direct word order in sentences; predominance of simple, unexpended sentences; distinct manifestation of style individualization [10, p. 65].

Scholars classify the press release as the dynamic news type of texts and among the main stylistic features of the press release they point out actuality that determines the credibility of the information provided (names, dates, quantitative indicators); brevity, clarity, conciseness of the material $[13 ; 2]$.

The researched material shows that the news release is characterised by:

- impersonal form of presentation. For example: "The research revealed that while the pandemic caused accelerated digital change in financial services, small businesses still want, and need, banking relationships" [14];

- inadmissibility of non-literary vocabulary: jargons, slang, colloquialisms, etc;

- limited use of professional terminology. For example: "This is the result of $M L$-enabled automation for the production of multi-format, multi-domain, speech, audio, text, image, natural language and computer vision data, which are used to fuel mission critical AI models for federal and enterprise customers" [15];

- use of neutral vocabulary and phraseology. For example: "Small businesses have options when it comes to technology and platforms designed to make their lives easier" [14];

- limited use of emotionally evaluative and expressive means. When used, this lexis serves the purpose of drawing an addressee's attention to the most significant part. For example: "The post-pan- demic rebirth of small businesses in the U.S. will create enormous opportunities for the banking industry" [14];

- use of repetitions to reinforce the presented idea and anchor it in the addressee's mind. For example: "Small businesses are considered the lifeblood of the American economy, and banking relationships are the lifeblood of small businesses" [14];

- use of quotes to enhance the credibility of the presented information. For example: "We are thrilled with the new efficiencies and productivity gains offered by the semi-automation of audio and video labeling tasks inside the Workbench," said Katie Nguyen, SVP Data Operations. "Our portfolio of data sets and services continues to rapidly expand with new and diverse offerings for our customer base" [15].

The main typological features of a news release are determined by the purpose of PR-communication: the news release should be informative, easy to understand, contain factual information.

The analysed material shows that modern news releases posted on the specialised cites on the Internet tend to incorporate images into the text of the message, that is definitely a peculiar characteristic feature of the news releases of the 21st century comparing with the second millennium ones, that followed a rigid structure where images were not welcome. In the majority of cases, the images are the companies' logos, the use of which is aimed at facilitating the company recognition among potential and prospective customers as well as anchoring in the addressee's mind the company's logo with a certain range of a product or service.

For example [16]:

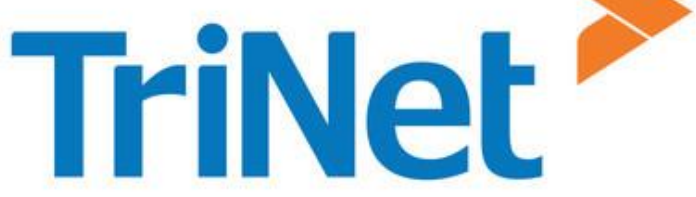

\section{Incredible starts here.}

The images imbedded in the text of the news release can also comprise a picture of a certain product or a video about it [17].

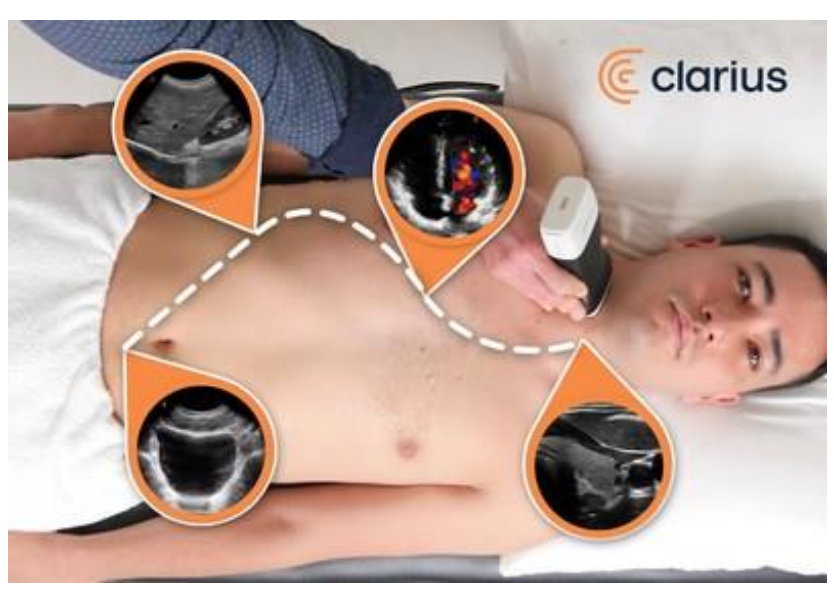

For example, the use of the photo given above promotes both the innovative product, namely a sophisticated ultrasound system, 
and the company itself as the logo is clearly visible in the right-hand top corner.

An addressee of the $21^{\text {st }}$ century is a savvy Internet user who is more likely to be persuaded into buying a certain product or service with the help of a carefully measured printed word reinforced by a vivid image. In this aspect the following universal functions of an image comes to the fore: an attractive function, aimed at drawing an addressee's attention and facilitating visual perception of the text; an informative function - to convey certain information; an expressive function - to express the addresser's feelings and influence the addressee's ones. As the news releases nowadays often encompass the companies' logos, the writers of the releases rely heavily on the symbolic function of the image that helps to express abstract notions and ideas via visual, sensory percepted images. For example [18]:

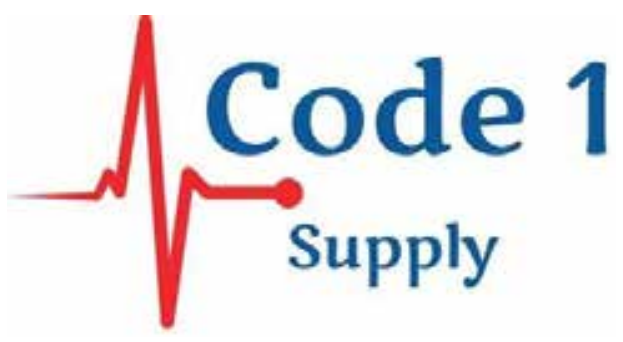

The use of the cardiac waveforms in the company logo is sure to trigger in the addressee's mind the connection of the company with Healthcare system as the cardiac waveforms belong to the images-symbols that have conventional, fixed meaning.

The researched material shows that in the structure of the news release the image comes either right below the headline or after an introductory paragraph. In some news releases the picture or a $\log _{0}$ can be placed at the end of the text. It serves the purpose of reinforcing the addressee's attention to the product or the company.

For example, in the news release published by Eagle Hill Consulting we come across both the picture of frustrated employees that is placed right after the introductory paragraph:

"ARLINGTON, Va., May 18, 2021 /PRNewswire/ -- More than one in three (36 percent) of U.S. employees working in the financial services industry are frustrated with technology, according to new research from Eagle Hill Consulting. Also, 21 percent report that technology makes their job harder. Only about half (48 percent) of financial services employees say their company prioritizes providing technology to make their jobs easier" [19]:

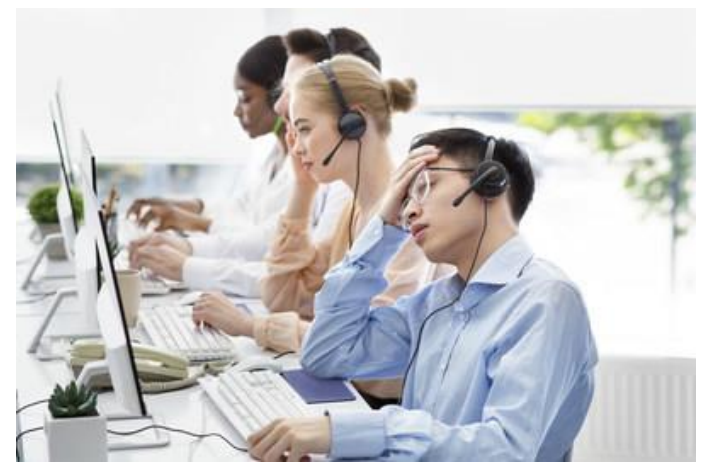

and the company $\log 0$ at the end [19]:
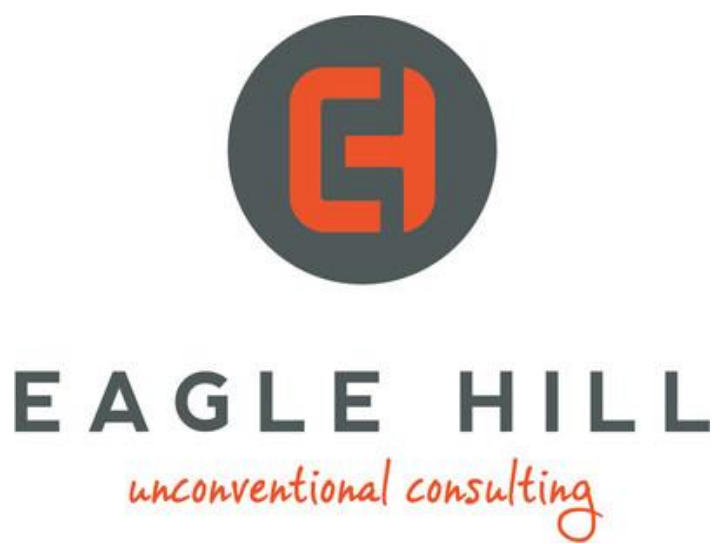

The first picture (with the employees) performs the illustrative function as due to visually perceived images it helps to convey the information presented in the text of the news release and enhance the information credibility in the addressee's eye.

The researched material shows that structure of the news release resembles an "inverted pyramid" where each subsequent paragraph contains less important information. The news release includes: 1) a title; 2) an announcement-paragraph, containing a summary of the main idea of the article (a lead paragraph) that can be followed by an image a company logo or a picture; 3 ) a paragraph that reveals the essence of the information event (a key body paragraph); 4) quotations; 5) some background information; 6) a final paragraph containing information about the organization / company.

The title of a news release usually consists of six or fewer words; the main purpose of the title is to attract the attention of a potential reader and inform him about the content of the news release. The lead / announcement contains the main facts of the news and answers the questions "Who?", "What?", "Where?", "When?", "Why?". The size of this section does not usually exceed 40 words. This is followed by a paragraph that reports the facts and details that complement the information in the announcement paragraph. Quotes from experts, top authorities of the company are used in the text of the news release to support the main idea of the publication. Background information is meant for the recipients who have addressed this issue for first time and may not know the history of the event. The final paragraph contains basic information about the organization and projects mentioned in the news release, as well as contact information: the address of the official website; name, postal and e-mail addresses and telephone number of the contact person (s) of the company.

Conclusions and prospects for further research. The thorough analysis of the research material shows that the modern news release as a peculiar genre of the PR-discourse is characterised by the following features: preference of impersonal form of information presenting, avoidance of non-literary lexis, such as jargons, slang, colloquialisms, by limited use of professional terminology, predominance of emotionally neutral vocabulary and phraseology, limited use of emotionally evaluative and expressive means, repetitions usage to reinforce the presented idea and anchor it in the addressee's mind, quotes use to enhance the credibility of the presented information. The structural elements of a news release are: a title; an announcement-paragraph, presenting the key idea of the news release; a paragraph that reveals the essence of the information event; quotations; some background information; a final paragraph containing information about the company or organisation. Modern 
news releases posted on the specialised cites on the Internet tend to incorporate images into the text of the message, that is definitely a peculiar characteristic feature of the news releases of the 21 st century. In the majority of cases, the images are the companies' logos, the use of which is aimed at facilitating the company recognition among potential and prospective customers as well as anchoring in the addressee's mind a strong connection between the company's $\log _{0}$ and a certain range of a product or service.

The prospects of further research we see in the comprehensive analysis of the news release texts from the position of visual semantics in the aspect of the addressee influencing.

\section{References:}

1. Collins Dictionary. URL: https://www.collinsdictionary.com/ dictionary/english/news-release (дата звернення: 23.05.2021).

2. Catenaccio P. Press releases as a hybrid genre: addressing the informative/promotional conundrum. Pragmatics. 2008. P. 9-31.

3. Robberts J. Writing the press release. Practical Pre-School. 1997. No 5. DOI:https://doi.org/10.12968/prps.1997.1.5.41565

4. Winston P. H. Make It Clear: Speak and Write to Persuade and Inform. Cambridge, Massachusetts, London. The MIT Press. 2020 DOI: https://doi.org/10.7551/mitpress/12406.003.0042

5. Brown Jarreau P. When quotes matter: impact of outside quotes in a science press release on news judgment. Journal of Science Communication. 2014. No 13(04). A02. DOI: https://doi.org/10.22323/ 2.13040202

6. Davis A. K., Piger J.M., Sedor L.M. Beyond the Numbers: Measuring the Information Content of Earnings Press Release Language. DOI: https://doi.org/10.1111/j.1911-3846.2011.01130.x URL: https:// onlinelibrary.wiley.com/doi/abs/10.1111/j.1911-3846.2011.01130.x (дата звернення: 23.05.2021).

7. Guillamon-Saorin E., Osma B.G., Jones M. Opportunistic disclosure in press release headlines. Accounting and Business Research. 2012. No 42 (2). P. 143-168, DOI: https://doi.org/10.1080/00014788.2012.6 32575

8. Maat H.P., Jong C. How newspaper journalists reframe product press release information. Journalism. 2013, No 14 (3). P. 348-371. DOI: https://oi.org/10.1177/1464884912448914

9. Superceanu R. Intertexuality and informativity of press releases : factors determining the communication between PR practitioner and journalist. Professional communication and translation studies. 2011. P. 21-30.

10. Мантуло Н.Б. PR-дискурс як система вираження інформації: жанровий аспект. Держава та регіони. Серія: Соціальні комунікаиії. 2010. С. $116-120$.

11. Демин Ю.М. Бизнес-РR. Москва : Бератор-Пресс, 2003. 336 с.

12. Єгорова Л.Г. Іміджевий текст: лінгвопрагматичний і лінгвокультурологічний аспекти : автореф. дис. ... канд. філол. наук : спец. 10.02.02. Сімферополь, 2009. 20 с.

13. Потапенко С.І. Сучасний англомовний медіа-дискурс: лінгвокогнітивний і мотиваційний аспекти. Ніжин : НДУ ім. М. Гоголя, 2009. $391 \mathrm{c}$.

14. Small Business-Banking Relationships Are Challenged by Rising Expectations, New CI\&T Report Finds. URL: http://stage.mediaroom. com/smallbusinesspr/News_Releases?rkey=20210521SF86017\& fil ter=16081 (дата звернення: 23.05.2021).

15. AppTek's Workbench Delivers $85 \%$ More Efficiency in Computer Vision and Speech Recognition Data Labeling Tasks. URL: http://
stage.mediaroom.com/smallbusinesspr/News Releases?rkey $=202105$ 21PH85988\&filter=16081 (дата звернення: 23.05.2021).

16. TriNet Webinar: Recruiting and Onboarding in a Virtual or Hybrid Environment. URL: https://www.smallbusinesspr.com/News_Rel eases? $\mathrm{rkey}=20210519 \mathrm{SF} 82995 \&$ filter=16081 (дата звернення: 23.05.2021).

17. Clarius Introduces First Ultrasound System That Uses AI and Machine Learning to Recognize Anatomy for an Instant Window into the Body. URL: https://www.smallbusinesspr.com/News_Releases?rkey=20210 519PH82737\&filter=16081 (дата звернення: 23.05.2021).

18. Cape Cod's Code1Supply Enables Businesses to Keep Safety at Forefront. URL: https://www.smallbusinesspr.com/News_Releases?r key=20210519PH83832\&filter=16081 (дата звернення: 23.05.2021).

19. More Than One-Third of Financial Services Employees Frustrated with Technology, New Eagle Hill Research Finds. URL: https://www. smallbusinesspr.com/News_Releases?rkey=20210518PH81376\&fil ter=16081 (дата звернення: 23.05.2021).

Ємельянова О. В., Новітченко В. О. Лінгвопрагматичні особливості сучасного англомовного прес-релізу

Анотація. У статті розглянуто лінгвопрагматичні особливості англомовного прес-релізу. Визначено, що англомовний прес-реліз є складником дискурсу паблик рилейшнз (PR-дискурсу), який націлений на формування позитивного іміджу компанії у свідомості цільової аудиторії. Прес-реліз $є$ коротким повідомленням, метою якого $\epsilon$ інформування адресата про будь-яку подію в житті компанії або установи та створення позитивного впливу на аудиторію. Способи впливу залежать від цільової аудиторії та комунікативної ситуації.

Описано характерні особливості прес-релізів, як-от інформативність, актуальність, достовірність, конкретність, стислість, простота, універсальність, технологічність, які вливають на ефективність повідомлення. Визначено, що прес-реліз є синкретичним типом тексту, який поєднує в собі офіційно-діловий, публіцистичний і рекламний функціональні стилі. Це зумовлює властивість прес-релізу виконувати одночасно кілька комунікативних функцій. Зазначено, що основні риси тексту прес-реліз реалізуються на лексичному, граматичному і синтаксичному рівнях. Описано основні лінгвостилістичні особливості сучасного прес-релізу. Досліджено основні типологічні ознаки прес-релізу, які визначаються метою PR-комунікації, та зауважено, що культурна специфіка є одним із факторів, що визначають те, якими засобами досягається ефект впливу на адресата.

Проаналізована структура прес-релізу. Прес-реліз експліцитно дає відповідь на ключові питання що, коли, де та орієнтує адресата протягом всього тексту прес-релізу. Досліджуваний матеріал свідчить, що сучасний прес-реліз, базуючись стандартних вимогах до цього типу тексту, а саме: достатньо жорсткому форматі, стислості та чіткості представлення матеріалу, обмеженості обсягу, що не має перевищувати сторінку формату А4 для зручності сприйняття, інкорпорує малюнки та фотографії, щоб підсилити вплив на адресата.

Ключові слова: PR-дискурс, прес-реліз, адресат, лінгвостилістичні особливості, зображення, прагматичний вплив. 